\title{
FINANCING AS A KEY FACTOR OF THE STRATEGY OF SUSTAINABLE RURAL TOURISM DEVELOPMENT IN THE REPUBLIC OF SERBIA ${ }^{1}$
}

\author{
Gordana Radović2 ${ }^{2}$ Kristina Košić ${ }^{3}$, Dunja Demirovićc ${ }^{4}$
}

\begin{abstract}
Summary
The important reason for the lack of rural tourism development, in most rural areas in Serbia, is undefined strategic development directions and the lack of financial investment. The aim of this paper is to highlight the need for the adoption of the strategy for sustainable development of rural tourism in the actual transition period in the Republic of Serbia, with clearly defined development priorities and modalities of financing for all segments of rural tourism offer. The adoption of this strategy is necessary in the Republic of Serbia, in the actual transition period, in order to develop rural areas, to reduce regional differences in economic development, and in order to stop actual depopulation process of rural areas. Defining innovative and additional sources of funding is necessary, because the existing are limited and insufficient. The paper used a method of analysis and synthesis, descriptive, and comparative method.
\end{abstract}

Key words: rural tourism, development, financing, strategy, the Republic of Serbia JEL: $018, Q 01$

\section{Introduction}

The Republic of Serbia has comparative advantages for the development of rural tourism due to the fact that $85 \%$ of its territory (according to the categorization of the Organization for Economic Cooperation and Development (OECD)), consists of rural areas. The favourable geographical position, rich historical and cultural heritage, preserved traditional village

1 The paper is a result of the project „Effects of rural tourism development in Vojvodina“ no.142-451-3683/2017-01/02 supported by the Provincial Secreteriat for the Higher Education and Scientific-Research Activity.

2 Gordana Radović, Ph.D, Scientific associate, Director, „Dnevnik-Poljoprivrednik“ AD Novi Sad, Serbia, e-mail: gordana.radovic09@gmail.com (corresponding author)

3 Kristina Košić, Ph.D, Associate Professor, University of Novi Sad, Faculty of Sciences, Department of Geography, Tourism and Hotel Management, Trg Dositeja Obradovića 3, Novi Sad, Serbia, e-mail: tinicaus@yahoo.com

4 Dunja Demirović, PhD, Researcher, University of Novi Sad, Faculty of Sciences, Department of Geography, Tourism and Hotel Management, Trg Dositeja Obradovića 3, Novi Sad, Serbia, e-mail: demirovic.dunja2@gmail.com

EP 2018 (65) 1 (413-426) 
architecture, attractive ethnic characteristics, numerous ethnographic and gastronomic events, as well as the traditional hospitality of the population are among the resources of rural tourism. Rural tourism in the Republic of Serbia started to develop in the 70-ies of XX century. This was the beginning of rural tourism, not only in Serbia but also in the whole of the Socialist Federal Republic of Yugoslavia (Marković et al., 2012).

Development of rural tourism in the Republic of Serbia, in actual transition period, is a possibility, but also a necessity, because in spite of the many quality resources, rural areas are generally underdeveloped. The current development of rural tourism in the Republic of Serbia can not be compared with the development of this type of tourism in European countries with a similar length of the developmental period. The reason for this are varied and numerous factors on both sides - the offer and the demand side of tourism. These are, above all, political, economic, social, legal and regulatory, institutional, organizational and management factors. Political events in the last decade of the twentieth century were unfavorable and caused devastating effects on the tourism industry, especially in the rural tourism, which has just started to develop. The disintegration of the Socialist Federal Republic of Yugoslavia, wars in the region, international sanctions, the bombing of areas of the Republic of Serbia, have left a negative impact on the natural, physical, social, human and financial resources and caused long-term stagnation in the development of rural tourism offer and demand.

The economic crisis, which is continuously present in the whole transition period, caused restrictive investment in the maintenance of transport and utility infrastructure, lack of maintenance of existing accommodation capacities in rural areas, as well as reduced investments in the maintenance of cultural and historical monuments, events and all the factors that shape rural tourist facilities. On the other hand, lower purchasing power caused a drop in demand for rural tourism products. This phenomenon is especially pronounced at the beginning of the second decade of the XXI century and is the result of socio-economic factors - the "disappearance of the middle class", which has traditionally been a consumer of the rural tourism product.

Legal and regulatory framework of rural tourism in the Republic of Serbia began to form in recent years, but it is still not compatible with the needs of service providers and focused on the rapid development of the industry. At the same time, the development of rural tourism limits unresolved institutional, organizational and management issues. All of the above adverse factors have a common bond, and those are finances, or the lack of funding models, both on tourism offer and demand side. Sources of funding are, if not sufficient, but certainly a necessary condition for the development of tourism and their quantity, quality and continuity are of great importance for the dynamic development of rural tourism.

These factors are the reason that at the end of the first decade of XXI century, only 514 or $0.7 \%$ of the total of 631,552 agriculture entities are dealing with rural tourism in the Republic of Serbia (Census of Agriculture, 2012, p. 190-197). Also, rural tourism in the Republic of Serbia is undevelopment. The greatest number of service providers engaged in rural tourism are present in Šumadija and Western Serbia (Table 1). 
Table 1. The territorial distribution of agricultural households in the Republic of Serbia engaged in rural tourism

\begin{tabular}{|l|c|}
\hline \multicolumn{1}{|c|}{ Name of the Region } & Number of farms engaged in tourism \\
\hline Belgrade Region & 14 \\
\hline Vojvodina Region & 93 \\
\hline Region Šmadija and West Serbia & 295 \\
\hline Region South and Eastern Serbia & 112 \\
\hline Region Kosovo and Metohija & - \\
\hline Total & 514 \\
\hline
\end{tabular}

Source: Census of Agriculture 2012 - Agriculture in the Republic of Serbia (2012): Volume II, National Institute for Statistics, Belgrade, pp.190-197.

The Republic of Serbia is one of the most rural European countries, while in rural areas "dominate the diversification of household income, not the diversification of the industry" (Bogdanov, 2007, p. 53). The representation of rural tourism in other profitable activities on agriculture entitets is the largest in the territory of Vojvodina (1.11\%), while in the Belgrade region is only 0.48\% ( Bogdanov et al., 2014).

Development of rural tourism would have positive economic and financial effects on the level of service providers (frequently agriculture entites), on the level of local economic communities, as well as at the macro level and at the state level, in actual transition period . In particular, the development of rural tourism would allow the diversification of the rural economy, additional income for rural population, would reduce unemployment and differences in economic development between rural and urban areas. Development of rural tourism would allow the evaluation of the work of women, as well as the employment of young people and elderly residents, who are statistically listed as inactive working rural population. At the same time, it would enable the creation of new jobs, which could encourage the migration of population from cities to villages, for the purpose of employment. The Republic of Serbia mainly exports primary (unprocessed) agricultural products, while rural tourism is a possibility for food products to be sold on the domestic market to foreign tourists, and to realize the "invisible exports" and foreign exchange inflow.

\section{Literature review}

According to the definition that is widely accepted within the European Union, rural tourism comprises all tourist activities that can be implemented in rural areas. Rural tourism is one of the work most intensive industries, which represents a potential contribution to creation of new workplaces and economic development of rural areas, which is often the most important element in rural development strategies (Mitchell et al., 2005). According to the attitude of the World Tourism Organization, the highest economic importance of rural tourism is that this activity helps poverty elimination (Jing, 2006). According to the same author, rural tourism is mainly developed in areas that have limited financial resources, but have extraordinary natural resources, which could be a platform for economic development. 
Authors Roberts and Hall (2003) highlighted that rural tourism can be a relatively "sensitive" element of rural development. These authors classified financial resources among the limiting factors of development. More specifically, they state that investments, the opening of new businesses and employment may be limited due to the small tourist traffic. Also, the tourist season is often short, which causes a short period for the implementation of revenue, or for "supply of capital". Examples of the European countries, which have developed rural tourism, confirm that financial support is necessary for the development of this activity from the state in the initial stage.

External support, i.e. support of institutions at the local, regional and national level is very important, because its absence may be one of the reasons for the failure. Lack of investment, education, experience and inefficient marketing are the main reasons for the termination of small businesses in rural areas or are the barriers for the entry to the tourist market (Sharpley, 2002). Financial support for rural tourism development was present in each country which developed this activity during transition period. The possibility of obtaining financial support, favourable bank loans or providing other innovative modalities of financing represents one of the key factors that ensure the development of rural tourism.

Financing of rural tourism is complex because it is closely related to the financing of agriculture. Authors Todorović and Stetić (2009) pointed out that there is an important link between agriculture and tourism. These economic activities are mutually complementary and multiply connected. Agriculture is a producer, and tourism a consumer of agricultural products. In the Republic of Serbia, the financing of agriculture is constant and the unresolved problem of the domestic economy (Radović, 2014). Adverse economic and financial situation of agriculture causes that entities do not have sufficient "economic strength" to independently develop tourism activities on their holdings (to earn additional income and improve living standards). According to Svržnjak and associates (2014) financing is usually the most difficult part of the development path for rural tourism due to the fact that some studies suggest that finding ways for funding, requires the most time (resources) for making (implementation) of development projects.

Radović (2013) pointed out that the problems in the development of rural tourism in Serbia are numerous. Primarily, it is the lack of financial resources, lack of defined standards and register of rural tourism, insufficient offer of tourist attractions, as well as undeveloped local infrastructure and tourist signaling. One of the problems is a lack of association of service providers, their education, as well as the incompatibility of rural tourism service providers defined in legal solution with the current situation in practice. Large development problem is the underdevelopment of tourism intermediation or insufficient involvement of travel agencies in the promotion and sale of rural tourism products.

Some authors (Niskanen et al., 2007) pointed out that rural areas of Europe are facing with rapid economic changes caused by the decline in the profitability of agriculture and the lack of additional sources of income. The same authors stated that rural tourism has 
been recognized in many countries as a method of diversification of economic activities, as well as a factor in the stabilization of the rural population. The development of this type of tourism can contribute to reducing disparities between regions (especially between urban and rural areas), and can be a significant source of additional (or base) household income.

Ateljević (2007) stated that by the end of the twentieth century in Europe, a large number of studies were connected with the operation of small tourist enterprises and were focused on rural tourism, with special emphasis on the sector of accommodation, but still greater attention is paid to the major travel companies located in the urban areas. Studies have shown that one of the most important characteristics of small and medium-sized enterprises is striving to overcome difficulties in securing funding for their survival, growth and development. Also, Vos and associates (2007) pointed out that small businesses, more than any others, are faced with a lack of finances and that problem is particularly acute in countries in transition due to uncertainty in the availability of financial resources, business profitability, market trends and unequal distribution of profits.

Small businesses and agricultre households in Serbia, are facing with a lack of financial resources, which causes the need for the development of innovative financing modalities. According to Vujović, Vukosavljević and Bjeljac (2014), self-financing is the dominant current form of financing for (rural) tourism in the Republic of Serbia.

\section{The aim, methodology and data sources}

The aim of this paper is to highlight the need to adopt a sustainable development strategy of rural tourism in the Republic of Serbia, as a special development document, with clearly defined development priorities and modalities of financing for the development of all segments of rural tourism.

Defining innovative and additional sources of funding for development rural tourism in the Republic of Serbia is necessary, because the existing are limited and insufficient (Radović, 2016). The adoption of this strategy is necessary in the Republic of Serbia, in the actual transition period, in order to develop rural areas, to reduce regional differences in economic development, and in order to stop actual depopulation process of rural areas.

The main hypothesis in the paper is: Rural tourism in Serbia is underdeveloped due to the lack of strategy of rural tourism and high-quality sources of funding. The paper used a method of analysis and synthesis, descriptive, and comparative method. Descriptive, as well as the method of analysis is used to analyze the current legislative framework and defined sources of funding in accordance with it. The analysis of the available literature, and within it the most popular forms of financing of rural tourism, were used to define the potential modalities of financing, which should be an important segment of the Strategy of sustainable development of rural tourism in Serbia, whose adoption is proposed in this paper. 


\section{Results}

In order to prove the main hypothesis, we conducted research which consisted of two parts. The first part of the research included the analysis of the current legislative framework and in compliance with it the defined mode of financing rural tourism in Serbia. The second part of the research involved the analysis of the available literature, and within in the most popular forms of financing of rural tourism.

\section{Analysis of the current legislative framework}

The normative framework for the financing of rural tourism in the Republic of Serbia is strategically and legally defined by: (a) The Law on Agriculture and Rural Development; (b) The Law on Incentives in Agriculture and Rural Development; (c) Tourism Development Strategy of the Republic of Serbia for the period from 2016 to 2025; (d) the Strategy for Agriculture and Rural Development of the Republic of Serbia for the period 2014-2024; (e) Master Plan for sustainable development of rural tourism in the Republic of Serbia; (f) Program of development of sustainable rural tourism in the Republic of Serbia; (g) Marketing strategy of tourism of the Autonomous Province of Vojvodina.

The Law on Agriculture and Rural Development defines that agricultural and rural development policies in the Republic of Serbia include measures and activities taken by the relevant authorities, and within them the most important for the development of rural tourism are: (a) measures to provide support to rural development; (b) measures to ensure high quality and healthy food; (c) measures to protect the environment from the negative impacts of agricultural production.

The Law on Incentives in Agriculture and Rural Development regulates the nonrepayable funding of agriculture and rural development from the state budget, where all kinds of incentives are defined, as well as the conditions for entitlement to them and methods for their use. Incentives for development of rural tourism are comprised within the incentive for the improvement of the rural economy, which are implemented in order to improve the quality of life in rural areas. This group of incentives includes: (1) investments for the improvement and development of rural infrastructure; (2) the improvement of economic activities in the village through the support for nonagricultural activities; (3) the economic activity in terms of adding value to agricultural products, as well as the introduction and certification of safety and food quality, organic products and products with indications of geographical origin; (4) improving training in the field of rural development. The Law on Incentives in Agriculture and Rural Development has determined that the right to incentives could be given to agricultural holdings registered in the Register of agricultural households. The law also specifies that the beneficiaries of incentives are required to use funds for that purpose, and the obligation of the Ministry of Agriculture to keep the Register of incentives.

Tourism Development Strategy of the Republic of Serbia for the period from 2016 to 2025 defines only two measures of support and investment. Those are grants and loans with a lower interest rate. Grants are of small amounts and are intended to co-finance 
various projects and activities in tourism. Loans for co-financing investments in tourism are with a lower interest rate than the market and are sold through the Development Fund of the Republic of Serbia. In order to develop tourism, defined by the Strategy, the new measures, programs and institutions for supporting the tourism development should be created according to the structure of entities that can realistically generate new entrepreneurship and innovation programs and investment projects, taking into account their size and possible real contribution to the development of tourism. In this Strategy are listed and public-private partnerships, as possible financial instrument and model for rural tourism development.

Strategy for Agriculture and Rural Development of the Republic of Serbia for the period 2014 - 2024 puts the diversification of the rural economy, which needs to be implemented, in priority development goals: (1) a diverse offer of products and services of rural households; (2) development of rural tourism; (3) increase in number of products and services based on the local identity of rural areas; (4) protection and preservation of cultural heritage; (5) strengthening the vertical and horizontal coordination of actors in rural development; (6) the improvement of utility and land infrastructure.

Master plan for sustainable development of rural tourism in Serbia is a project in whose creation were involved: Ministry of Agriculture, Forestry and Water Management, Tourism Department of the Ministry of Finance and Economy, Tourist Organization of Serbia (TOS) and five UN agencies: The Food and Agriculture Organization (FAO), The World Tourism Organization (UNWTO), the Fund for Children (UNICEF) and the United nations Development Programme (UNDP). The national government has, on the basis of this project, adopted a Program of development of sustainable rural tourism in the Republic of Serbia, in November 2011.

Program for development of sustainable rural tourism in the Republic of Serbia defines that the main objective of this document is diversification of the rural economy through the reduction of poverty, improvement of quality of life, preservation of the cultural wealth of the country, environmental protection and balanced regional development. The Program also defines limits for the development of rural tourism in the Republic of Serbia: (a) lack of awareness of population in rural communities about the values of natural and cultural resources and tourism potentials; (b) insufficient capacity for rural tourism; (c) lack of managerial and organizational links to national, regional and local level, which is essential for the management of rural tourism in an efficient and sustainable manner. Twelve territorial regions - clusters of rural tourism on the territory of the Republic of Serbia, where this form of tourism should be a development priority, were determined by the Program. Clusters that were grouped into four groups are: Central and Western Serbia, Southern Banat and lower Danube, Eastern Serbia and cluster consisting of Vojvodina and the upper Danube.

Marketing strategy for tourism of the Autonomous Province of Vojvodina defines the development of rural tourism in Vojvodina as a tourist product of high potential.

Based on the analysis of the current legislative framework, it can be concluded that 
rural tourism is recognized as a key factor in the development of rural economies and opportunities and constraints for the development of this type of tourism are defined, but they are not sufficiently discussed and sources of funding are not defined. In particular, financial limited grants, which are placed from the state budget, are defined only, and these grants are inadequate source of financing for (rural) tourism. Also, as a source of financing are defined and loans with lower interest rate, but here, the state budget funding source subsidizing interest rates, and this modality of financing is limited.

It can be concluded that the analysis proved that the defined sources of funding in the current regulatory framework are limiting factor for the development of rural tourism in the Republic of Serbia. This confirmed the auxiliary hypothesis $\mathrm{H}_{2}$. In order to develop rural tourism in Serbia, additional, innovative funding modalities for rural tourism are required. Therefore, this paper proposes the adoption of specific rural development strategy, which should define and other terms of financing that would enable the development of this type of tourism in the Republic of Serbia, in actual transition period.

\section{Possible modalities of financing for rural tourism in the future strategy}

The analysis of the available literature, and within it the most popular forms of financing of rural tourism, were used to define the potential modalities of financing, which should be an important segment of the Strategy of sustainable development of rural tourism in Serbia, in actual transition period.

In order to develop rural tourism in the Republic of Serbia, it is necessary to adopt the Strategy for the sustainable rural tourism development, as a special development document. This Strategy should enable the sustainable development of this type of tourism from the economic, ecological and sociological aspects. Also, it is necessary that potential funding modalities are also defined in the Strategy of development of rural tourism. In addition to the existing means of financing, mainly based on state support and loans of commercial banks, it is important to implement in the domicile financial system also new financial institutions, as well as new funding modalities. The strategy should be written for the next ten-year period, and should include the development of all forms of rural tourism, that already exist, and can also be developed in the Republic of Serbia. It is necessary to define the method of financing of rural tourism offer in the narrow sense (accommodations and hospitality), and infrastructure, education of rural tourism operators, as well as the development of tourist attractions, promotions and sales channels.

Available literature offers a few popular modalities for financing the rural tourism, so we compared them with the results of the survey research and formulated potential modalities for financing rural tourism in the Republic of Serbia. Those are:

(a) Microcredit organizations;

(b) Joint venture;

(c) Business angels;

(d) Public-private partnerships (PPP); 
(e) Specialized Agricultural Bank (SAB);

(f) Pre-accession funds of the European Union.

Microcredit organizations - The need to innovate financial system in the Republic of Serbia is located in the current economic literature. For example, Šoškić (2017) emphasizes the need for the introduction of non-bank credit institutions in the domestic financial system, and, above all, savings and credit cooperatives and microfinance institutions. These institutions could also be an important source of funding for rural tourism.

These financial institutions would be able to get actively involved in financing the development of rural tourism in the Republic of Serbia due to the fact that they have an important role in supporting the development of entrepreneurship and self-employment category of the population that have no access to conventional banking market. In addition to activating the unemployed, investments of microcredit organizations are also important for ensuring the necessary sources of financing to farmers who do not have a continuous source of income, necessary to get loans from commercial banks, but they have a vision for the development of rural tourism. According to (Erić et al., 2012) microloans primarily mean providing financial services to individuals with lower incomes in order to start their own business and be economically independent and strong.

There are great opportunities and needs of investments of microcredit organizations in order to develop rural tourism. This applies primarily to the development of the tourist offer, i.e. construction of accommodation facilities, the development of restaurants and tourist attractions. The limiting factor for the application of lending by microcredit organizations in the Republic of Serbia is the lack of legal framework for their operation. Therefore, microcredit organizations have to invest their loans through commercial banks, which significantly increase this way of financing.

Joint venture is a specific form of foreign direct investment with the owner of the capital not acting independently, but in cooperation with local partner (Andrić et al., 2005). The importance of financing through joint ventures is that the funds are obtained from foreign partners without the cost of financing, and tangible and intangible assets are obtained without purchase, which is positive for micro and macro aspect, for it has a favourable effect on the balance of payments. The essence of the joint ventures is that partners share profit, but also the risks and losses of joint engagement in proportion with the invested funds. Obligations of partners are defined by the contract, whose period of validity can be linked to the period until the invested funds from profit of joint work are refunded, but also to the longer period.

Joint ventures can be an important modality of financing the development of all segments of the rural tourism in the Republic of Serbia. For example, joint ventures can be realized between domestic rural tourism entities (rural tourism households, rural hotels or ethno village) with foreign investors. They could jointly finance construction for example of an aqua park within the municipality which has the developed rural tourism. In this kind of funding could also be actively involved representatives of diaspora, who originate from the municipality in which the investment is planned. 
Business angels - Financing the development of rural tourism in the Republic of Serbia can be achieved also through "business angels" as a kind of non-institutional private investors who invest in entrepreneurial firms, in the initial stage of their development. These investors typically have sustainable professional experience, and have free financial resources and necessary contacts, so they want to invest their professional wisdom in start-up companies so that they could have successful business and development, but also to verify their business reputation (Eric et al., 2012). In most cases, the invested money is not returned but is exchanged for co-ownership and exactly this characteristic distinguishes "business angels" from micro-credit organizations.

Financing through "business angels" can be implemented in order to develop small and medium enterprises in the field of rural tourism in the Republic of Serbia. It is particularly suitable for newly established micro enterprises, which do not have the "credit history'. It is adequate for financing of all segments of the rural tourism offer: the construction or reconstruction of accommodation facilities, development of restaurants and tourist attractions, training and development of staff and leaders, as well as for financing of promotion. The advantage is that this way of financing and consulting is free of charge and profit-oriented, which synergistically may be a generator of development of rural tourism. This modality of financing could especially be interesting to people from the diaspora, who would in this way be able to invest free capital, but also to implement their experience and business contacts, and take active role in the development of rural tourism in the Republic of Serbia.

Public-private partnerships (PPP) as a form of business cooperation emerged in the 90 s of the $20^{\text {th }}$ century in the United States, where it was originally used to finance education, municipal services and infrastructure (Yescombe, 2010). Public-private partnership is a method that connects the interest of the public sector (common good), private sector (profit) and civil sector (special interests) in meeting the specific needs to increase the quality and/or availability of services and products (Perić et al., 2006). The same authors believe that this method of financing is used for the purposes for which the public sector has insufficient funds, while the private sector does not have enough interest to individually invest funds. Therefore, their most common use is in financing the construction or reconstruction of transportation or utility infrastructure. Public-private partnerships provide funding without paying the cost of financing, through them the business risk is divided, and greater availability of funds from the European Union is also allowed. This method of financing could be applied to finance construction or reconstruction of infrastructure in rural areas in the Republic of Serbia, which could initiate the development of rural tourism, and consequently rural, regional and overall economic development of the country and the region.

Specialized Agricultural Bank (SAB) - Establishment of Specialized Agricultural Bank of the Republic of Serbia is necessary in order to develop agriculture, but also non-agricultural activities, i.e. rural tourism in the context of agricultural holdings. The Specialized Agricultural Bank loans should be with lower interest rates and other favourable conditions of lending. For that purpose, Specialized Agricultural Bank requires providing specific structure of funds, which could only be provided with the 
support from the state, and the state should have a crucial role in policy lending funds, which would be in line with economic, social, but also strategic objectives related to the need for the development of rural tourism in Serbia. It is important to arrange the establishment and operations of Specialized Agricultural Bank (SAB) by a special law, which should define the initial capital and sources of financing, as well as operations, i.e. business objectives, and in accordance to them also lending conditions. It is essential to prevent the centralization of resources and decision-making, as well as the political influence on the management of the bank (Radović, 2014).

Favorable loans, placed by Specialized Agricultural Bank, could be a quality and a significant source of funding for the development of all segments of the rural tourism supply side. Specifically, these loans could be used to finance the construction of accommodation facilities, for the development of tourism facilities, education, and for the development of tourist services through the development of organic food production.

Pre-accession funds of the European Union - By receiving the status of candidate on March 1st 2013, the Republic of Serbia won the right to use funds from the IPARD pre-accession component. IPARD is the most complex IPA component and it comprises measures that can be grouped into three axes. Financing of rural tourism is implemented via third axis measures that include activities related to the development of rural infrastructure and diversification of the rural economy. For the development of rural tourism from the aspect of the individual entity the most important measure is 302, and within it happen the following investments: (a) in construction and/or reconstruction and/or equipping of facilities for provision of tourist and hospitality services; (b) facilities for the breeding of animals for tourism purposes; (c) facilities for recreational activities; (d) tourist camps; (e) facilities outdoors (thematic tracks, equestrian tracks, etc.); (f) the restoration of old buildings (traditional architecture). Financing from IPARD is realized on the principle of co-financing. More specifically, for the financing of projects part of the funds is provided from the Fund, and part has to be financed from domestic funds, the participation of the public sector can be up to $50 \%$, while the rest of the funds have to be provided from the resources of the private sector. In order to implement the measures of the third axis it is necessary to provide funds for co-financing at a minimum of $10 \%$, and at a maximum of $50-70 \%$ of the project value. The Republic of Serbia, within IPARD in the program period from 20142020, has available 175 million Euros, or 230 million Euros, if we take into account also funds from national funds. IPARD funds are not yet available to rural tourism stakeholders in Serbia due to administrative reasons.

\section{Conclusion}

The authors believe that the lack of quality sources of financing is the biggest limitation for the development of rural tourism in the Republic of Serbia. Rural tourism entities do not generate adequate profits that would allow them to self-finance their activities, and existing funding modalities are inadequate or insufficient. Therefore, the authors advocate defining innovative financing modalities. 
In order to resolve the problem of financing rural development and rural tourism, authors propose the adoption of a new strategy, which will primarily deal with the problem of financing, as a fundamental development problems of rural areas in the Republic of Serbia, in actual transition period. Also, it is necessary to define the modalities of financing of all segments of the rural tourism offers: accommodation facilities, hospitality sector, tourist attractions, promotion, sales channels, as well as the development and training of staff, and development of rural infrastructure.

Authors analyzed available literature and suggest the introduction of new institutions in the domestic financial system, such as micro-credit organizations and Specialized Agricultural Bank which require redefinition of the legal framework. Also, it is necessary to include in the financing of rural tourism, as stated in the current Strategy for Agriculture and Rural Development, and the pre-accession funds of the European Union (IPARD), but also the potential modalities of financing, such as public-private partnerships, joint ventures, and "business angels" as innovative funding modalities in the Republic of Serbia. The abovementioned potential modalities of financing should be a part of the future rural tourism development strategy, as well as their active application in practice. Development of rural tourism can induce rural development in order to ensure the reduction of different level of economic development between regional region in order to stop the actual depopulation of rural areas in the Republic of Serbia.

\section{References}

1. Andrić, J., Vasiljević, Z., Sredojević, Z. (2005): Investicije - osnove planiranja $i$ analize, Univerzitet u Beogradu, Poljoprivredni fakultet, Beograd, Srbija.

2. Ateljević, J. (2007): Small tourism firms and management practices in New Zealand: The Centre Stage Macro Region, Tourism Management, Vol. 28, pp. 307-316.

3. Bogdanov, N. (2007): Mala ruralna domaćinstva u Srbiji i ruralna nepoljoprivredna konomija, UNDP, Beograd, Srbija.

4. Bogdanov, N., Babović, M. (2014): Radna snaga i aktivnosti poljoprivrednih gazdinstava, Republički zavod za statistiku, Beograd, Srbija.

5. Erić, D., Beraha, I., Đuričin, S., Kecman, N., Jakšić, B. (2012): Finansiranje malih i srednjih preduzeća u Srbiji, Institut ekonomskih nauka, Beograd, Srbija.

6. Jing, X. (2006): Rural Tourism and Sustainable Community Development, International Forum on Rural Tourism, China, 4.-6- September 2006., Final Report World Tourism Organization.

7. Marković, S., Ostojić, M. (2012): Četiri decenije seoskog turizma u Moravičkom kraju, Prva konferencija o ruralnom turizmu i održivom razvoju, Kragujevac, Srbija, Zbornik radova, str. 28-40.

9. Mitchell, M., Hall D. (2005): Rural Tourism as Sustainable Business: Key Themes and Issues, in Rural Tourism and Sustainable Business, Hall D., Kirkpatrick I. and Mitchell M. (eds), pp. 3-14, Channel View Publications, Clevedon, Buffalo, Toronto. 
10. Master plan održivog razvoja ruralnog turizma u Republici Srbiji (2011): Zajednički program UN „Održivi turizam u funkciji ruralnog razvoja“, Beograd, Srbija.

11. Marketing strategija turizma Vojvodine (2009): Sekretarijat za privredu, Pokrajinske Vlade, AP Vojvodina, Novi Sad, Srbija.

12. Nacionalna asocijacija "Seoski turizam Srbije", http://www.selo.co.rs.

13. Niskanen, A., Slee, B., Ollonqvist, P., Pettenella, D., Bouriaud, L., Rametsteiner, E. (2007): Entrepreneurship in the forest sector in Europe, University of Joensuu, Faculty of Forestry, Silva Carelica.

14. Perić, J., Dragičević, D. (2006): Partnerstvo javnog i privatnog sektora, Fintrade \& tours d.o.o, Rijeka, Hrvatska.

15. Popis poljoprivrede (2012): Sveska II, Republički zavod za statistiku, Beograd, Srbija. 16. Program razvoja održivog ruralnog turizma u Republici Srbiji, Službeni glasnik Republike Srbije br. 85/2011.

17. Radović, G. (2013): Problemi razvoja ruralnog turizma u Republici Srbiji, Agroekonomika, Vol. 59-60, pp. 114-123.

18. Radović, G. (2014): Finansiranje poljoprivrede u Republici Srbiji, Zadužbina Andrejević, Beograd, Srbija.

19. Radović, G. (2016). Sources of finance for rural tourism in the Republic of Serbia, Economics of agriculture, Vol. LXIII, No3/2016, pp. 1053-1065.

20. Republički zavod za statistiku (2013): Popis poljoprivrede 2012 - Poljoprivreda u Republici Srbiji, Sveska 1 i 2, Beograd, Srbija.

21. Roberts, L., Hall, D. (2003): Rural tourism and recreation: principles to Practise, CABI Publishing, Oxon, UK.

22. Sharpley, R. (2002): Rural tourism and the challenge of tourism diversification: The case of Cyprus, Tourism Management, Vol. 23, pp. 233-244.

23. Svržnjak, K., Kantar, S., Jerčinović, S., Kamenjak, D. (2014): Ruralni turizam uvod u destinacijski menadžment, Visoko gospodarsko učilište, Križevci, Hrvatska.

24. Stojković, M.H. (2006): Statistika - Deskriptivna i statička analiza, Univerzitet u Novom Sadu, Ekonomski fakultet, Subotica, Srbija.

25. Strategija poljoprivrede i ruralnog razvoja Republike Srbije za period 2014.-2024. Službeni glasnik RS br.85/2014.

26. Strategija razvoja turizma Republike Srbije za period 2016-2025 (2016), Vlada Republike Srbije, Ministarstvo trgovine, turizma i telekomunikacija, Beograd, Srbija. Retrived from: http://mtt.gov.rs/download/3/strategija.pdf

27. Šoškić, D. (2017): Monetary and Financial Prerequisits of Higher Growth Rates in Serbia, Ekonomika preduzeća, Vol. 1-2, pp. 103-112.

28. Todorović, M., Štetić, S. (2009): Ruralni turizam, Univerzitet u Beogradu, Geografski fakultet, Beograd, Srbija.

29. Yescombe, E.R. (2010): Javno-privatna partnerstva, načela politike i financiranje, EP 2018 (65) 1 (413-426) 
Mate d.o.o., Zagreb, Hrvatska.

30. Vos, E., Yeh, A.J., Carter, S., Tagg, S. (2007): The happy story of small business financing, Journal of Banking \& Finance, Vol. 31, pp. 2648-2672.

31. Vujić S. (2007): Uloga i perspektive mikokreditnih organizacija u razvoju seoskog turizma, Acta turistica, Vol. 19, No. 2, pp. 101-228.

32. Vujović, S., Vukosavljević, D., Bjeljac, Ž. (2014): Financing tourist activity, J. Geogr. Inst. Cvijic, Vol. 64, No. 2, pp. 207-214.

33. Zakon o podsticajima u poljoprivredi i ruralnom razvoju, Službeni glasnik Republike Srbije br. 10/2013.

34. Zakon o poljoprivredi i ruralnom razvoju, Službeni glasnik Republike Srbije br.41/2009.

\title{
FINANSIRANJE KAO KLJUČNI ELEMENT STRATEGIJE ODRŽIVOG RAZVOJA RURALNOG TURIZMA U REPUBLICI SRBIJI
}

\author{
Gordana Radovićc ${ }^{\text {, Kristina Košić }}{ }^{6}$, Dunja Demirović ${ }^{7}$
}

\begin{abstract}
Sažetak
Jedan od značajnih faktora koji utiče na neadekvatan razvoj ruralnog turizma, $u$ većini ruralnih oblasti u Srbiji, je nepostojanje definisanih strateških pravaca razvoja, neadekvatan uticaj državne administracije, a posebno nedostatak investicija, na nacionalnom i lokalnom nivou, za razvoj ruralne infrastrukture. Cilj rada je da se istakne potreba donošenja Strategije održivog razvoja ruralnog turizma u Republici Srbiji,u aktuelnom tranzicionom periodu. Strategija bi trebalo da ima jasno definisane razvojne prioritete i modalitete finansiranja svih segmenata ruralne turističke ponude. Definisanje inovativnih i dodatnih izvora finansiranja je neophodno jer su postojeći izvori ograničeni i nedovoljni.
\end{abstract}

Ključne reči: ruralni turizam, razvoj, finansiranje, strategija, Republika Srbija

5 Dr Gordana Radović, naučni saradnik, direktor, „Dnevnik-Poljoprivrednik“ AD Novi Sad, Srbija, e-mail: gordana.radovic09@gmail.com (autor za korenspodenciju)

6 Dr Kristina Košić, vanredni profesor, Univerzitet u Novom Sadu, Prirodno-matematički fakultet, Departman za geografiju, turizam i hotelijerstvo, Trg Dositeja Obradovića 3, Novi Sad, Srbija, e-mail: tinicaus@yahoo.com

7 Dr Dunja Demirović, istraživač, Univerzitet u Novom Sadu, Prirodno-matematički fakultet, Departman za geografiju, turizam i hotelijerstvo, Trg Dositeja Obradovića 3, Novi Sad, Srbija, e-mail: demirovic.dunja2@gmail.com 